\title{
PENERAPAN MODEL PEMBELAJARAN EXAMPLES NON-EXAMPLES UNTUK MEMPERBAIKI PROSES PEMBELAJARAN PADA MATA PELAJARAN GAMBAR TEKNIK KELAS X TKBB SMK NEGERI 2 SURAKARTA TAHUN AJARAN 2016/2017
}

\author{
Ilham Arrezha ${ }^{1}$, A.G. Tamrin², Sukatiman ${ }^{3}$
} iarrezh@gmail.com

\begin{abstract}
ABSTRAK
Proses pendidikan saat ini memperlihatkan banyaknya siswa yang kurang aktif selama proses pembelajaran. Proses pembelajaran hanya terfokus pada guru semata yang berdampak pada kurangnya pemahaman siswa terhadap materi yang diajarkan. Penelitian ini bertujuan untuk mengetahui penerapan model pembelajaran Examples Non-Examples terhadap kinerja guru, keaktifan siswa dan hasil belajar siswa.

Penelitian ini merupakan penelitian tindakan kelas yang dilaksanakan di kelas X TKBB SMK N 2 Surakarta yang berjumlah 31 siswa. Penelitian ini dilaksanakan dalam dua siklus. Setiap siklus terdiri dari tahap perencanaan, pelaksanaan, observasi, dan refleksi. Instrumen penelitian yang digunakan terdiri dari penilaian penampilan guru, penilaian kinerja guru oleh siswa, penilaian kognitif, psikomotorik, dan afektif. Uji validitas menggunakan data menggunakan trianggulasi dan analisa data menggunakan analisis deskriptif kuantitatif menggunakan statistik deskriptif.

Hasil penelitian menunjukkan bahwa penerapan model pembelajaran Examples Non-Examples dapat memperbaiki kinerja guru dan keaktifan siswa. Pada setiap siklus yang dilakukan, juga meningkatnya hasil belajar siswa, hal ini berarti meningkatnya kinerja guru juga berdampak pada meningkatnya hasil belajar siswa
\end{abstract}

Kata kunci : Examples Non-Examples, Kinerja Guru, Keaktifan

${ }^{3}$ Pengajar Program Studi Pendidikan Teknik Bangunan FKIP Universitas Sebelas Maret 


\title{
APPLICATION OF LEARNING MODEL EXAMPLES NON-EXAMPLES TO IMPROVE LEARNING PROCESS IN LEARNING EYE FIGURE TECHNIQUE CLASS X TKBB SMK NEGERI 2 SURAKARTA TAHUN AJARAN 2016/2017
}

\author{
Ilham Arrezha ${ }^{1}$, A.G. Tamrin², Sukatiman ${ }^{3}$ \\ iarrezh@gmail.com
}

\begin{abstract}
The current education process showedthe number of students who were less active during the learning process. Thelearning process only focuses on the teacher alone which affects the lack ofstudents' understanding of the material being taught. This study aimed todetermine the application of learning models Examples Non-Examples on teacherperformance, student activeness and student learning outcomes. This researchwere classroom action research conducted in class $X$ TKBB SMK N 2 Surakarta,amounting to 31 students. This study was conducted in two cycles. Each cycleconsists of planning, implementation, observation, and reflection. The researchinstrument used consisted of teacher performance appraisal, student performanceappraisal by teacher, cognitive, psychomotor, and affective assessment. Thevalidity test used triangulation data and the data analysed using descriptive quantitative analysis using descriptive statistics. The results showed that the application of learning model Examples Non-Examples can improve teacher performance and student activeness. In each cycle, as well as the increase in student learning outcomes, this means increased teacher performance also had an impact on increasing student learning outcomes.
\end{abstract}

Keywords: Examples Non-Examples, Teacher Performance, Activeness 


\section{PENDAHULUAN}

Undang-Undang

Sistem

Pendidikan Nasional No 20 Tahun

2003 Pasal 1 (1) berbunyi:

Pendidikan adalah usaha sadar dan terencana untuk mewujudkan suasana belajar dan proses pembelajaran agar peserta didik secara aktif mengembangkan potensi dirinya guna mencapai tujuan pendidikan.

Sesuai dengan tujuan pendidikan nasional tersebut, sekolah diharapkan mampu mengembangkan potensi peserta didik agar menjadi manusia yang beriman dan bertakwa kepada Tuhan Yang Maha Esa, dan menjadi warga negara yang bela negara serta bertanggung jawab. Sekolah sebagai lembaga pendidikan formal secara sistematis merencanakan dan menyediakan fasilitas pendidikan untuk melakukan berbagai kegiatan belajar. Dengan adanya tujuan pendidikan maka akan menentukan kemana arah peserta didik akan dibawa.

Penjelasan lain dari UndangUndang yang diatas menyatakan bahwa pembelajaran adalah proses interaksi peserta didik dengan pendidik dan sumber belajar pada suatu lingkungan belajar. Guru memegang peranan yang sangat penting dalam proses pembelajaran dan merupakan salah satu komponen yang menentukan keberhasilan proses belajar. Sebab, guru merupakan ujung tombak yang secara langsung berhubungan dengan siswa.

Jursusan Teknik Konstruksi Batu Beton merupakan salah satu jurusan yang diselenggarakan oleh SMK Negeri 2 Surakarta, dengan tujuan untuk membekali siswa dengan dasar akademik dan kemampuan keterampilan agar siswa dapat bekerja sesuai dengan keahliannya. Dalam mata pelajaran Gambar Teknik, siswa dituntut untuk dapat menggambar benda 3D secara gambar sketsa dan gambar rapi sesuai aturan proyeksi pictorial. Namun fakta pelaksanaan di lapangan, pada mata pelajaran Gambar Teknik khususnya di SMK Negeri 2 Surakarta cenderung kurang maksimal dalam hasil belajar. Hal ini masih ditemukan berbagai masalah yang muncul dalam pembelajaran, salah satunya metode pembelajaran yang digunakan adalah domian ceramah. Dengan kata lain siswa lebih cenderung pasif karena pembelajaran hanya berpusat pada guru. Hal tersebut terlihat pada sikap siswa saat mengikuti proses pembelajaran, yaitu ditemukannya bahwa siswa masih asik mengobrol dengan temannya dan bermain gadget, kurang merespon terhadap materi yang disampaikan, dan tidak memperhatikan guru saat pembelajaran. Selain itu dalam menyampaikan materi pengajar tidak menampilkan contoh-contoh berupa gambar maupun cara menggambar dengan benar, sehingga siswa masih mengalami kesulitan dalam memahami, mempelajari dan menggambar. Hal ini membuat proses pembelajaran menjadi kurang efektif khususnya pada mata pelajaran Gambar Teknik.

Media Dari data yang diperoleh hasil observasi di SMK Negeri 2 Surakarta pada mata pelajaran Gambar Teknik Tahun Ajaran 2016/2017 khususnya pada pokok bahasan pengenalan jenis 
gambar proyeksi dan menggambar proyeksi hanya ada $31,25 \%$ (10 siswa) dari 32 siswa yang mendapat nilai sesuai KKM yang ditentukan yaitu 76.

Adanya masalah tersebut peneliti mempunyai pemikiran yaitu perlu diupayakan menggunakan metode yang lain, sehingga proses dalam pembelajaran ini diharapkan bisa mengatasi masalah tersebut dan memudahkan siswa untuk memahami materi yang diajarkan oleh guru. Pembelajaran ini juga diharapkan mampu memperbaiki proses pembelajaran siswa. Proses dalam pembelajaran Gambar Teknik menggunakan model Example NonExample. Dalam pelaksanaan pembelajaran tersebut bisa tidak hanya berpusat pada guru melainkan siswa juga dituntut untuk aktif serta dalam proses pembelajaran. Dalam pembelajaran menggunakan model Examples Non-Examples siswa dapat berkomunikasi dan bekerja sama antar siswa. Sehingga hal ini dapat meningkatkan dan memperbaiki proses pembelajaran Gambar Teknik di SMK N 2 Surakarta tahun pelajaran 2016/2017.

Berdasarkan

identifikasi

masalah di atas maka tujuan penelitian tindakan kelas ini adalah sebagai berikut: 1) Mengetahui penerapan model pembelajaran Examples Non-Examples dapat memperbaiki kinerja guru, meningkatkan keaktifan belajar dan hasil belajar siswa pada mata pelajaran Gambar Teknik siswa kelas $\mathrm{X}$ program keahlian Teknik Konstruksi Bangunan di SMK N 2 Surakarta tahun pelajaran 2016/2017. 2) Memperbaiki kinerja guru pada mata pelajaran Gambar Teknik menggunakan model pembelajaran Examples Non-Examples siswa kelas $\mathrm{X}$ program keahlian Teknik Konstruksi Bangunan di SMK N 2 Surakarta tahun pelajaran 2016/2017. 3) Meningkatkan keaktifan dan hasil belajar siswa dengan menerapkan model pembelajaran Examples NonExamples pada mata pelajaran Gambar Teknik siswa kelas $\mathrm{X}$ program keahlian Teknik Konstruksi Bangunan di SMK N 2 Surakarta tahun pelajaran 2016/2017.

\section{Penelitian Tindakan Kelas}

Berdasakan berbagai sumber seperti Mettetal (2003), Kardi (2000), dan Nur (2001), Penelitian Tindakan Kelas (PTK) atau classroom action research (CAR) didefinisikan sebagai penelitian yang dilakukan oleh guru di dalam kelasnya sendiri melalui refleksi diri, dengan tujuan untuk memperbaiki kinerjanya sebagai guru, sehingga hasil belajar siswa menjadi meningkat. Dalam model penelitian ini, si peneliti (guru) bertindak sebagai pengamat (observer) sekalligus sebagai patisipan.

Menurut Lewin (Tahir 2012:77), PTK merupakan siasat guru dalam mengaplikasikan pembelajaran dengan berkaca pada pengalamnya sendiri atau dengan perbandingan dari guru lain.

Menurut Bahri

(2012:8), Penelitian Tindakan Kelas merupakan sebuah kegiatan yang dilaksanakan untuk mengamati kejadian-kejadian dalam kelas untuk memperbaiki praktek dalam pembelajaran agar lebih berkualitas dalam proses sehingga hasil belajarpun menjadi lebih baik. 
Dari beberapa pendapat di atas dapat disimpulkan bahwa PTK adalah tindakan yang terjadi di dalam kelas dengan melakukan tindakan untuk memperbaiki proses belajar mengajar dan didasarkan atas upaya untuk meningkatkan hasil belajar yang lebih baik.

\section{Pembelajaran}

Menurut Menurut Syaiful Sagala (2009) pembelajaran adalah membelajarakan siswa menggunakan asas pendidikan maupun teori belajar yang merupakan penentu utama keberhasilan pendidikan

Berbeda dengan Oemar Hamalik (2006) pembelajaran adalah suatu kombinasi yang tersusun meliputi unsur-unsur manusiawi, material fasilitas, perlengkapan dan prosedur yang saling mempengaruhi tercapainya tujuan pembelajaran.

Dari beberapa pendapat di atas dapat disimpulkan bahwa pembelajaran adalah suatu rangkaian peristiwa yang dirancang dan disusun secara sistematis untuk dapat memberikan pengaruh yang komplek bagi siswa baik berupa ucapan, pikiran maupun tindakan.

\section{Model Pembelajaran}

Slavin (2010) model pembelajaran adalah suatu acuan kepada suatu pendekatan pembelajaran termasuk tujuannya, sintaksnya, lingkungannya, dan sistem pengelolaannya.

Selanjutnya Trianto (2009) model pembelajaran merupakan pendekatan yang luas dan menyeluruh serta dapat diklarifikasikan berdasar tujuan pembelajarannya, sintaksnya (pola urutannya), dan sifat lingkungan belajarnya.

Sedangkan menurut Joyce (1992) dalam Rohman dan Amri (2013) model pembelajaran adalah suatu pola yang digunakan sebagai pedoman dalam merencanakan pembelajaran di kelas atau pembelajaran dalam tutorial dan untuk menentukan perangkatperangkat pembelajaran termasuk di dalamnya buku-buku, film, komputer, kurikulum, dan lain-lain.

Berdasarkan Dari beberapa pendapat para ahli dapat disimpulkan bahwa model pembelajaran adalah suatu pola yang digunakan untuk mengelola kelas dalam merencanakan aktivitas belajar mengajar. Tidak hanya satu model pembelajaran saja yang dapat digunakan karena model pembelajaran sangat banyak dan dapat digunakan sesuai dengan materi yang akan disampaikan.

\section{Model Pembelajaran Examples Non-Examples \\ Model pembelajaran}

Examples Non-Examples merupakan salah satu model pembelajaran inovatif yang dapat diterapkan kepada siswa. Penerapan model ini dimulai dengan siswa menganalisis contoh-contoh berupa gambar yang sesuai dengan kompetensi dasar kemudian siswa mempresentasikan hasil diskusinya. Pelaksanaanya dengan cara diskusi kelompok.

Langkah-langkah model pembelajaran Examples NonExamples menurut Agus Suprijono (2009) adalah sebagai berikut :

1. Guru mempersiapkan berbagai gambar yang disesuaikan dengan tujuan pembelajaran. 
2. Guru menyajikan atau menampilkan gambar lewat LCD atau alat pendukung lainnya.

3. Guru memberikan arahan dan kesempatan kepada siswa untuk mengamati dan menganalisa gambar-gambar yang telah disajikan.

4. Siswa mencatat hasil analisa dari gambar setelah melakukan diskusi kelompok yang terdiri 2-3 siswa.

5. Tiap kelompok diberi kesempatan untuk membacakan hasil diskusinya.

6. Mulai dari komentar ataupun hasil diskusi siswa, guru mulai menjelaskan materi sesuai dengan tujuan yang ingin dicapai.

7. Guru bersama-sama para siswa menyimpulkan materi sesuai dengan tujuan pembelajaran.

\section{Kinerja Guru}

Lindsay and Patrick dalam (Hasan, 2004:17) lebih menekankan kepada perilaku orang yang melaksanakan pekerjaan tersebut, selanjutnya ia menyatakan," kinerja guru adalah perilaku yang berhubungan dengan penyelesaian pekerjaan yang di harapkan, spesifik atau bersifat normal oleh setiap anggota organisasi". Mitriani dalam (Hasan 2004: 17) menyatakan, "kinerja adalah perangkat proses untuk menciptakan pemahaman bersama mengenai apa yang harus di capai, bagaimana hal itu harus dicapai serta bagaimana mengatur orang dengan cara meningkatkan kemungkinan tercapainya tujuan".

Beberapa pendapat di atas dapat di jelaskan bahwa kinerja tidak saja dilihat dari hasil suatu pekerjaan tetapi juga dapat dilihat dari perilaku seseorang dalam melaksanakan pekerjaannya.

\section{Keaktifan}

Menurut Kamus Besar Bahasa Indonesia berarti giat (bekerja, berusaha). Keaktifan adalah sesuatu kegiatan belajar yang ditandai adanya keterlibatan secara optimal, baik intelektual, emosional, dan fisik (Aunurrahman, 2009).

Lingren dalam Daryanto dan Rahardjo (2012) keaktifan adalah interaksi di antara siswa dengan guru dan siswa dengan siswa lainnya.

Dari pendapat di atas dapat disimpulkan bahwa keaktifan adalah keadaan dimana siswa dapat berinteraksi atau keterlibatan aktif dalam bentuk sikap pada proses belajar.

\section{Hasil Belajar}

Hasil belajar merupakan perubahan perilaku yang diperoleh pembelajar setelah mengalami aktivitas belajar. Perolehan aspekaspek perubahan tersebut tergantung dari apa yang dipelajar oleh pembelajar. Oleh karena itu jika pembelajar mempelajari pengetahuan tentang konsep, maka perubahan perilaku yang sesuai adalah penguasaan akan konsep.

Menurut W.S. Winkel (2009: 280-285) : Tujuan pendidikan yang hendak dicapai dapat diklasifikasikan menjadi tiga bidang, yaitu: Ranah Kognitif, Afektif, dan Psikomotorik

\section{METODE PENELITIAN}

Tempat penelitian tindakan kelas pada penelitian ini dilaksanakan di SMK Negeri 2 Surakarta JL. Adisucipto 33 Manahan Surakarta 57139. Telepon, 0271 714901. Waktu pelaksanaan penelitian dilakukan mulai bulan Januari 2017 sampai bulan Juli 2017. 
Subjek penelitian ini adalah guru dan siswa kelas X TKBB SMK Negeri 2 Surakarta tahun ajaran 2016/2017.

Teknik pengumpulan data yang digunakan yaitu dengan observasi, kajian dokumen, penugasan, tes. Data yang diambil dari dokumentasi video dan foto kegiatan pembelajaran mata pelajaran Gambar Teknik sebelum dan sesudah dilaksanakan tindakan, daftar hasil tes dan tes yang dilakukan.

Untuk menghasilkan
informasi yang akurat dan
memastikan kebenaran data, maka dalam penelitian ini menggunakan teknik triangulasi data. Menurut Sugiyono (2009) Triangulasi data diuraikan sebagai teknik pengumpulan data dan sumber data yang telah ada. Triangulasi data (sumber) yaitu mengumpulkan data sejenis dari sumber yang berbeda dan triangulasi peneliti yaitu mendiskusikan data yang diperoleh dengan peneliti yang lain. Peneliti menggunakan teknik triangulasi data karena dalam penelitian ini data diperoleh dari siswa Kelas X TKBB, Guru Mata Pelajaran Gambar Teknik, observasi, penugasan, dan hasil tes.

Teknik Pada penelitian ini teknik analisis data yang dilakukan secara analisis interaktif, yang terdiri dari reduksi data, penyajian data, dan penarikan kesimpulan dalam bentuk interaktif dengan pengumpulan data sebagai suatu proses siklus.

Indikator kerja yang
digunakan untuk pembelajaran dan kinerja guru mendapat nilai 75 untuk penampilan guru dan predikat B untuk penilaian siswa terhadap guru, sedangkan untuk ranah kognitif, afektif, dan psikomotorik sebanyak $80 \%$ siswa memperoleh nilai 76,00.

Prosedur dalam penelitian tindakan kelas model pembelajaran Examples Non-Examples sehingga menjadi perencanaan tindakan, pelaksanaan tindakan, observasi refleksi (Evaluate And Revise).

\section{HASIL TINDAKAN DAN PEMBAHASAN}

Hasil tindakan antar siklus ini meliputi hasil tindakan siswa sebelum dilakukannya model pembelajaran Examples NonExamples (pra siklus) dan sesudah diterapkannya model pembelajaran Examples Non-Examples (siklus I dan siklus II). Keaktifan siswa dalam mengikuti pembelajaran mengalami peningkatan dari siklus I menuju siklus II. Observasi hasil belajar siswa meliputi ranah kognitif, ranah afektif, dan ranah psikomotorik. Dari hasil yang diperoleh saat penelitian bahwa dengan menerapkan model pembelajaran Examples NonExamples pada siklus II mengalami peningkatan dari siklus I.

Dari hasil penelitian dapat dilihat bahwa penerapan model pembelajaran Examples NonExamples dengan kinerja guru dan hasil belajar siswa mengalami perbaikan setiap siklusnya. Peningkatan setiap indikator dalam penelitian dapat disajikan sebagai berikut:

Tabel 1. Pencapaian Kinerja Guru dalam Pembelajaran

\begin{tabular}{cc}
\hline \multirow{2}{*}{ Siklus } & Target Nilai \\
\cline { 2 - 2 } & $\begin{array}{c}\text { Penampilan Guru } \\
\text { Mengajar }\end{array}$ \\
\hline Pra Siklus & 63,54 \\
\hline
\end{tabular}




\begin{tabular}{cc}
\hline Siklus I & 75,00 \\
\hline Siklus II & 84,38 \\
\hline
\end{tabular}

Tabel 2. Pencapaian Penilaian Kinerja Guru oleh Siswa

\begin{tabular}{lc}
\hline \multirow{2}{*}{ Siklus } & Kinerja Guru \\
\cline { 2 - 2 } & Penilaan Siswa \\
\hline Pra Siklus & 2.48 (predikat C) \\
\hline Siklus I & 3.07 (predikat B) \\
\hline Siklus II & 3.12 (predikat B) \\
\hline
\end{tabular}

Tabel 4. Perandingan Keaktifan Siswa

\begin{tabular}{lcccc}
\hline Kegiatan & KS4 & KS3 & KS2 & KS1 \\
\hline Pra Siklus & 0 & 2 & 1 & 0 \\
\hline Siklus I & 11 & 18 & 4 & 0 \\
\hline Siklus II & 19 & 13 & 3 & 0 \\
\hline
\end{tabular}

Tabel 5. Perandingan Hasil Belajar Siswa

\begin{tabular}{lccc}
\hline Kegiatan & Kognitif & $\begin{array}{c}\text { Psikomo } \\
\text { torik }\end{array}$ & Afektif \\
\hline Pra Siklus & $32,26 \%$ & $52 \%$ & $41,94 \%$ \\
\hline Siklus I & $58,06 \%$ & $71 \%$ & $61,21 \%$ \\
\hline Siklus II & $80,65 \%$ & $84 \%$ & $80,65 \%$ \\
\hline
\end{tabular}

Proses pelaksanaan tindakan pra siklus peneliti mengadakan observasi kondisi kelas pada saat melaksanaan Program Pelaksanaan Lapangan (PPL). Hasil yang diperoleh bahwa siswa cenderung pasif dalam mengikuti proses pembelajaran. Dalam proses pembelajaran masih terdapat beberapa siswa yang sibuk dengan kegiatannya sendiri baik mengobrol dengan teman, tiduran dan bermain gadget pada saat melaksanakan proses pembelajaran. Pada hasil belajar ranah kognitif didapat nilai rata-rata kelas sebesar 70,54 dengan persentase ketuntasan 32,26\% (10 siswa dari 31 siswa). Dimana nilai rata-rata kelas yang diperoleh masih lumayan jauh dari KKM yaitu sebesar 76.

Dari keaktifan siswa dan hasil belajar siswa yang diperoleh masih jauh dengan tindakan yang telah ditetapkan. Hal ini terjadi karena siswa dalam mengikuti pembelajaran masih kurang aktif. Untuk menumbuhkan keaktifan siswa dalam proses pembelajaran maka dilakukan adanya model pembelajaran baru dengan menggunakan model pembelajaran Examples Non-Examples. Dalam model pembelajaran Examples NonExamples siswa dapat berkomunikasi dan bekerjasama antar siswa. Sehingga dapat memperbaiki dan meningkatkan hasil belajar siswa dalam proses pembelajaran.

Keaktifan siswa dalam pelaksanaan siklus I dalam mengikuti tugas diskusi kelompok sudah cukup aktif. Keaktifan diskusi dan keaktifan bertanya sudah cukup baik, hal ini dapat dilihat dari berkurangnya siswa yang kurang aktif dalam proses pembelajaran. Contohnya, pada keaktifan diskusi hanya terdapat 1 siswa yang kurang aktif dalam mengikuti diskusi dan untuk keaktifan bertanya masih ada 4 siswa yang malu bertanya apabila menemukan permasalahan.

Data hasil penelitian siklus II merupakan hasil refleksi dari siklus I untuk melakukan perbaikan di kekurangan pada siklus II. Pada siklus II mengalami peningkatan yang sangat baik dalam keaktifan siswa dan hasil belajar yang dicapai juga meningkat sudah mencapai indikator penelitian yang ditentukan. 
Keaktifan siswa dalam pelaksanaan siklus II mulai mengalami peningkatan. Pada siklus II pelakasanaan tugas diskusi dibagi menjadi 6 kelompok setiap kelompok terdiri dari 4-5 anggota dari sini keaktifan siswa yang dicapai mengalami peningkatan. Masingmasing kelompok sudah bertanggung jawab dalam pelaksanaan tugas diskusi. Adanya bimbingan dari guru apabila mengalami kesulitan membuat siswa berani untuk bertanya. Pada hasil ranah kognitif didapat rata-rata sebesar 80,00 dengan persentase ketuntasan $80,65 \%$ dengan 25 siswa dari 31 siswa. Hasih ranah afektif didapat rata-rata sebesar 81,05 dengan persentase ketuntasan $80,65 \%$ dengan 25 siswa dari 31 siswa. Pada hasil ranah psikomotorik didapat rata-rata sebesar 80,09 dengan persentase ketuntasan $84 \%$ dengan 26 siswa dari 31 siswa.

Keaktifan siswa dan hasil belajar siswa siklus II mengalami peningkatan sangat baik. Siswa sangat antusias dalam mengikuti proses pembelajaran. Hal ini dapat dilihat dari keaktifan siswa dalam bertanya ketika mengalami kesulitan dalam penyelesaian tugas diskusi kelompok maupun pada saat presentasi kelompok. Siswa tidak lagi malu bertanya kepada guru apabila mengalami kesulitan dan aktif memberikan pendapat maupun pertanyaan pada kelompok saat presentase. Kerjasama antar siswa sangat menonjol dalam menganalisis soal yang diberikan oleh guru.

Sedangkan hasil belajar siswa juga mengalami peningkatan, hal ini dapat dilihat dari ranah kognitif, ranah afektif, dan ranah psikomotorik semua mengalami kenaikan baik dari persentase ketuntasan maupun rata-rata kelas.

Hasil penelitian dengan menerapkan model pembelajaran Examples Non-Examples pada kelas $\mathrm{X}$ TKBB SMK Negeri 2 Surakarta terbukti dapat memperbaiki proses pembelajaran dan meningkatkan hasil belajar siswa. Semua aspek hasil belajar seperti ranah kognitif, ranah afektif, dan ranah pesikomotorik mengalami peningkatan nilai ketuntasannya. Hal ini sejalan dengan hasil penelitian yang dilakukan oleh beberapa peneliti sebelumnya. Mereka menyimpulkan bahwa dengan menggunakan model pembelajaran Examples Non-Examples dapat memperbaiki proses pembelajaran dan meningkatkan hasil belajar siswa.

\section{SIMPULAN}

Penerapan model pembelajaran Examples Non-Examples dapat memperbaiki kinerja guru dalam mata pelajaran Gambar Teknik pada kelas X Teknik Konstruksi Batu dan Beton SMK Negeri 2 Surakarta. Hal ini dapat dilihat pada saat pra siklus, kinerja guru berada pada kategori $\mathrm{C}$ dengan nilai 63,54 yang artinya kinerja guru masuk dalam kategori buruk, kemudian dilakukan tindakan sehingga menghasilkan peningkatan nilai kinerja guru menjadi 75,00 dan masuk dalam kategori B pada siklus I kemudian terus meningkat pada siklus II menjadi 84,38

Dengan menerapkan model pembelajaran Examples NonExamples pada mata pelajaran Gambar Teknik pokok bahasan pengenalan jenis-jenis proyeksi 
piktorial, keaktifan dan hasil belajar siswa dapat juga ditingkatkan karena proses pembelajaran yang sudah baik. Penerapan model pembelajaran Examples Non-Examples dari 31 siswa didapatkan nilai ranah kognitif rata-rata 80 dengan persentase ketuntasan $80,65 \%$. Kemudian untuk hasil ranah afektif didapatkan nilai rata-rata $81,05 \%$ dengan persentase ketuntasan $80,65 \%$. Sedangkan nilai ranah psikomotorik didapatkan ratarata 80,09 dengan persentase ketuntasan $84 \%$. Jadi, dapat disimpulkan bahwa kelas X TKBB SMK Negeri 2 Surakarta dengan menerapkan model pembelajaran Examples Non-Examples dapat meningkatkan hasil belajar pada ranah kognitif, ranah afektif, dan ranah psikomotorik.

\section{DAFTAR PUSTAKA}

Ali Imron. (1995). Pembinaan Guru di Indonesia. Jakarta: Pustaka Jaya.

Arikunto, Suhardjono, \& Supardi (2006). Penelitiam Tindakan Kelas, Jakarta: PT Bumi Aksara.

Aan, Surya Putra. (2012). Penerapan Metode Pembelajaran Examples Non-Examples Pada Mata Pelajaran Pekerjaan Mekanik Dasar Kelistrikan Kelas X di SMK Negeri 2 Yogyakarta. Yogyakarta: Universitas Negeri Yogyakarta (UNY)

Departemen Pendidikan Nasional, 2003. Undang-Undang Nomor 20 Tahun 2003, Tentang Sistem Pendidikan Nasional, Jakarta: Depdiknas
Muhibbin Syah. (2010). Psikologi Pendidikan Dengan Pendekatan Baru. Bandung: PT. Remaja Rosdakarya

Permendikbud Tahun 2014 Nomor 104 Tentang Penilaian Hasil Belajar Oleh Pendidik pada Pendidikan Dasar dan Pendidikan Menengah.

Winkel, WS. (2009). Evaluasi Program Pembelajaran. Pustaka Pelajar 